\title{
Dentistry during and after COVID-19 Pandemic: Pediatric Considerations
}

\author{
Anuraj Singh Kochhar ${ }^{1}$, Ritasha Bhasin² ${ }^{2}$, Gulsheen Kaur Kochhar ${ }^{3}$, Himanshu Dadlani ${ }^{4}$, Balvinder Thakkar $^{5}$, Gurkeerat Singh $^{6}$
}

\begin{abstract}
This article is a rumination on the outbreak of the dreaded coronavirus disease-2019 (COVID-19) pandemic which has engulfed both the developed and the developing countries, thereby causing widespread global public health concerns and threats to human lives. Although countries have made varied efforts, the pestilence is escalating due to the high infectivity. It is highly likely that dental professionals in upcoming days will come across COVID-19 patients and SARS-CoV-2 carriers, and hence must ensure a tactful handling of such patients to prevent its nosocomial spread. Despite the avalanche of information that has exploded in relation to this rapidly spreading disease, there is a lack of consolidated information to guide dentists regarding clinical management including precautions to take materials to use and postprocedure care, during and after the COVID-19 pandemic. Available sources of information have been analyzed, while relying on peer-reviewed reports followed by information available from the most respected authoritative sources, such as WHO, Centers for Disease Control and Prevention (CDC), and ADA. This review aims to provide a comprehensive summary from the available literature on COVID-19, its insinuation in dentistry, recommendations that have been published, and the actual in-practice implications, so a plan can be formulated and adapted to the circumstances of each dental practice during the pandemic and the times to follow.
\end{abstract}

Keywords: Coronavirus, COVID-19, Dentistry, Pediatric dentistry, Pedodontics.

International Journal of Clinical Pediatric Dentistry (2020): 10.5005/jp-journals-10005-1782

\section{INTRODUCTION}

Coronavirus disease-2019 (COVID-19) pandemic presented as a black swan event, later spreading its tentacles into almost all spheres of life. The carcinogenic consequences have made it the need of the hour that dental healthcare professionals understand the mortiferous effects of this dreaded disease in order to prevent its malignant spread.

The SARS outbreak was the first readily communicable infectious disease that the world faced in the 21st century. It was presumed not to be the last such contagion. ${ }^{1}$ The COVID-19 outbreak that was the first reported in the area of Wuhan, China, drastically developed into a public health quandary. ${ }^{2}$ WHO has declared a global emergency with millions of people presently in quarantine, self-isolation, or lockdown. ${ }^{3}$

Constant diligent efforts to curb the effects of the pandemic are being carried out but the situation is still escalating owing to the high transmissibility of the virus leading to a community spread. It is speculated that dental professionals will come across COVID-19 patients and SARS-CoV-2 carriers, and hence must ensure a careful handling of such patients to prevent its nosocomial spread.

Despite the avalanche of data that is available in relation to this disease, there is confusion due to a lack of consolidated information to guide dentists. The purpose of this review is to provide a comprehensive summary from the available literature on COVID-19, its insinuation in dentistry, recommendations that have been published, and the actual in-practice implications, so a plan of measures can be formulated and adapted according to the circumstances of each dental practice during the pandemic and the times to follow.

\section{Knowledge about SARS-COV-2 Relevant to Dentistry}

Initially, COVID-19 started as a zoonotic infection, but soon human transmission started through nosocomial routes and later viruses
${ }^{1}$ Dept. of Dental Surgery, Max Hospital, Gurugram, Haryana, India

${ }^{2}$ International Dentist Advanced Placement Program, Faculty of Dentistry, University of Toronto, Toronto, Canada

${ }^{3}$ Department of Pediatric and Preventive Dentistry, National Dental College and Hospital, Dera Bassi, Punjab, India

${ }^{4}$ Department of Periodontology, Kalka Dental College and Hospital, Meerut, Uttar Pradesh, India

${ }^{5}$ Jaipur Dental Hospital and Orthodontic Centre, Jaipur, Rajasthan, India

${ }^{6}$ Department of Orthodontics, Sudha Rustagi College of Dental Sciences and Research, Faridabad, Haryana, India

Corresponding Author: Himanshu Dadlani, Department of Periodontology, Kalka Dental College and Hospital, Meerut, Uttar Pradesh, India, Phone: +91 9911373910, e-mail: himdent@hotmail. com

How to cite this article: Kochhar AS, Bhasin R, Kochhar GK, et al. Dentistry during and after COVID-19 Pandemic: Pediatric Considerations. Int J Clin Pediatr Dent 2020;13(4):399-406.

Source of support: Nil

Conflict of interest: None

were found in respiratory droplets as well. ${ }^{4}$ This causes an alarming concern to dentists as they deal with the orofacial region. Also, of concern is the presymptomatic transmissibility for COVID-19, during the incubation period up to 14 days, with the mean of 5- 6 days which has been documented by aggressive reconnaissance of clusters of confirmed patients. ${ }^{5-7}$ This is buttressed by information, via contact-tracing efforts that few individuals can test positive for the disease 1-3 days before the development of symptoms. ${ }^{8}$ It is noteworthy that infectious droplets or aerosols are still a prerequisite for transmission.

Asymptomatic transmission has also been reported similar to presymptomatic, by measures of contact tracing, wherein an

(-) The Author(s). 2020 Open Access This article is distributed under the terms of the Creative Commons Attribution 4.0 International License (https://creativecommons. org/licenses/by-nc/4.0/), which permits unrestricted use, distribution, and non-commercial reproduction in any medium, provided you give appropriate credit to the original author(s) and the source, provide a link to the Creative Commons license, and indicate if changes were made. The Creative Commons Public Domain Dedication waiver (http://creativecommons.org/publicdomain/zero/1.0/) applies to the data made available in this article, unless otherwise stated. 
individual test positive for COVID-19, however, presents without any symptoms. ${ }^{3,6,7,9}$ Owing to the transmission by presymptomatic and asymptomatic patients, the high $\mathrm{R}_{0}$ (basic reproductive number/ infectious agent's epidemic potential) for SARS-CoV-2 which ranges between 1.4 and 6.5, with an average of 3.28, might be justified. ${ }^{10,11}$

Even in those who are symptomatic, several people with COVID-19 express only faint clinical presentation, such as cough, ${ }^{12}$ however, this is a cause of concern in dentistry, because, there is an increased exposure risk if performing or being present for an aerosol-generating medical procedure (AGMP). Aerosolgenerating medical procedure comprises tracheal intubation, extubation, cardiopulmonary resuscitation, nebulizer treatment, sputum induction, noninvasive ventilation, tracheostomy, manual ventilation prior to intubation, and bronchoscopy. ${ }^{12}$ However, surprisingly, there is no mention of dental procedures. ${ }^{13}$ Fomites and feco-oral are other possible transmission routes that require attention. Recent updates suggest the possible routes of entry to be via the exposure of mucous membranes of nose, mouth, and eyes, ${ }^{10,14}$ and raise the concern for hand hygiene by the dental team as well as patients. Another matter of concern is air conditioner airflow direction, which was implicated as a means of transmission in Guangzhou, China and was published by Centers for Disease Control and Prevention (CDC). ${ }^{15}$

\section{Clinical Features of COVID-19}

Knowledge of signs and symptoms of COVID-19 is important for the dental practitioners. An elaborate history must be taken and should include questions regarding any flu-like symptoms, ranging from cough, shortness of breath, fever, and diarrhea, trouble breathing persistent pain or pressure in the chest. Mildly symptomatic patients also report alterations in smell or taste in SARS-CoV-2 infections which often were the first apparent symptoms. Questions regarding the same by the dentist can also prove to be beneficial in the initial diagnosis by the dentist, but results must be interpreted with caution. ${ }^{16}$ Detailed medical history is imperative as presence of comorbidities (obesity, diabetes, hypertension, cardiovascular disease, pulmonary disease, and renal disease) have been found to be risk factors for the disease..$^{17,18}$

\section{Diagnostic Tests}

SARS-CoV-2 tests may either detect the virus itself [viral ribonucleic acid (RNA)]/antigens or detect the serological antibodies produced in response. ${ }^{19}$ Real-time PCR test which mainly makes use of a nasopharyngeal swab is still the confirmatory test. ${ }^{20,21}$ Rapid testing and monitoring which is hot off the fire, detects $\lg M, \lg A$, $\lg G$, or total antibodies, ${ }^{19}$ and can be used by the dental practitioners for in-clinic screening of patients, with the results being available within a short span of time. ${ }^{22}$ Of the many rapid test kits that have been developed recently, as on April 24, 2020, 45 have been approved by FDA $^{23}$ (Fig. 1).

However, dentists should be cautioned, as early in the disease a single nasopharyngeal swab for PCR test is only $70 \%$ sensitive. ${ }^{24}$ On the contrary, although the rapid test infers expedited diagnosis of COVID-19, false-negatives are a bigger problem which cannot be overlooked. Hoffman et al., stated that the precision of the test was $94.1 \%$ for $\operatorname{lgM}$ and $98 \%$ for $\lg G$, considering RT-PCR positive cases as true positives. Further they outlined that although a sensitivity of 69 and $93.1 \%$ for IgM and IgG was observed, the assay showed an overall specificity of 100 and $99.2 \%$ for $\lg M$ and $\lg G$, respectively. ${ }^{25}$ Similar results were obtained by the researchers at Cleveland clinic who in an unpublished report stated a false-negative rate of $14.8 \% .{ }^{26}$ Hence, one must be forewarned that a negative test alone should not be used as the sole basis for ruling out COVID-19 infections and making patient management decisions, instead should be supplemented with history, clinical signs and symptoms, radiological findings, and epidemiological information. ${ }^{27}$

To et al., found the presence of the novel coronavirus in selfcollected saliva specimens of $91.7 \%$ patients which might be a viable source for diagnosis. ${ }^{28}$ Also, a study by Wyllie et al. showed that the collection of saliva can be self-administered, more sensitive, and viable as compared to nasopharyngeal swabs and could make accurate SARS-CoV-2 testing a possibility, be it at home or in a dental setting with lower risk to healthcare workers. ${ }^{29}$

Another valuable tool that can be used as an adjunct in the dental clinics is pulse oximeter, which is fast, easy, noninvasive, and harmless, to detect silent hypoxia, in COVID-19 patients. This has become a recent topic for consideration but requires further studies to be validated. ${ }^{30}$

\section{Is Prophylaxis Beneficial?}

Prophylactic hydroxychloroquine or chloroquine for asymptomatic healthcare professionals while treating COVID-19 patients has been advocated by the Indian Council of Medical Research (ICMR). The advised prophylaxis with hydroxychloroquine $(400 \mathrm{mg}$ twice on day 1 , followed by $400 \mathrm{mg}$ once a week) is a matter of concern as it can cause an undue optimistic perception of a drug whose efficacy is not verified for the particular use, the advantages unseen, and the undesirable consequences, including potentially lethal cardiac arrhythmia in certain individuals, overlooked. ${ }^{31-33}$ Also, prophylaxis could last for the entire duration of the pandemic, and in countries where malaria is highly prevalent, appropriate resistance monitoring of Plasmodium species is needed. ${ }^{34}$ A chemoprophylaxis advice without reliable evidence might be questionable. ${ }^{30}$ Hence, risks vs benefits should be evaluated, a thorough medical assessment and physicians' approval for the same must be taken.

\section{Dental Management and Preventive Measures during and after COVID-19 Pandemic}

Sound knowledge of the spread of SARS-CoV-2 is required to prevent its transmission in the dental practice. Though numerous routes of infections exist in the dental scenario, aerosols are one of the predominant routes for transmission of pathogens including SARS-CoV-2, therefore stringent infection control measures are imperative. ${ }^{35-38}$ Thus, for patient screening and infection control, specific proposals and strategies for dental healthcare practice are critical. Dentists must abide by the most recent recommendations from International, Federal and local public health authorities. Before a patient comes to the clinic, a telephonic appointment must be made with the dentist.

\section{Telescreening and Teletriage}

Aggressive screening of patients, attendants, dental practitioners, and the staff should be performed for COVID-19. Patients must be enquired about any close contact with a known COVID-19 patient or symptoms including fever, dry cough, and shortness of breath over the phone and where possible, video call. It can help screen suspected COVID-19 patients and also identify whether the patient requires in-office treatment. ${ }^{2}$ Another recommended method by the CDC is an online bot nicknamed Clara which can act as a screening aid $^{39}$ (Fig. 2). 


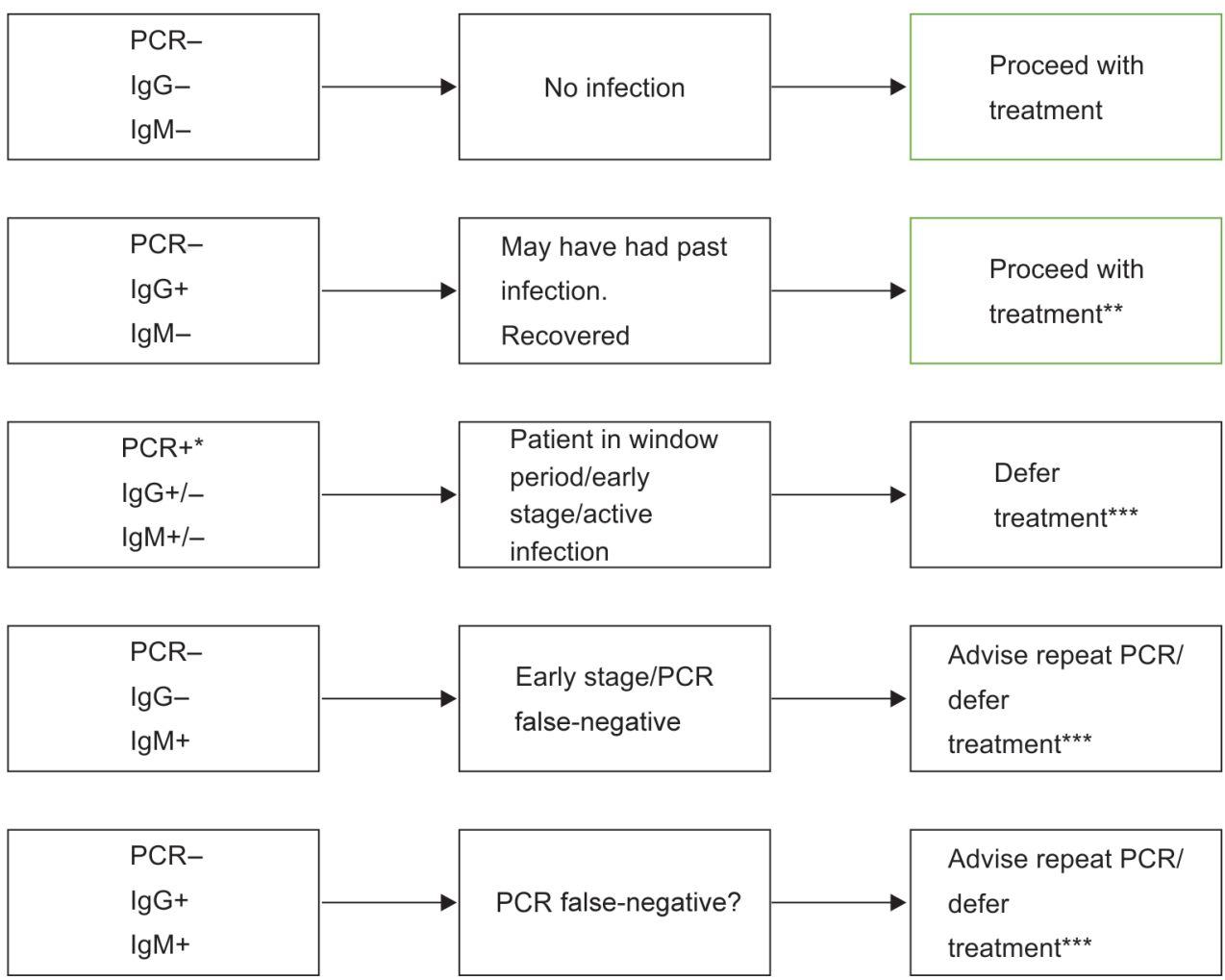

Fig. 1: Clinical significance of PCR and IgM/lgG serological test result.

*Positive PCR confirms infection. Antibody test not required

**Patient should be treated with caution in accordance with most updated CDC guidelines, as no information still available about infectivity during convalescence ${ }^{3}$

***Treatment to be carried out after CDC guidelines fulfilled ${ }^{3}$

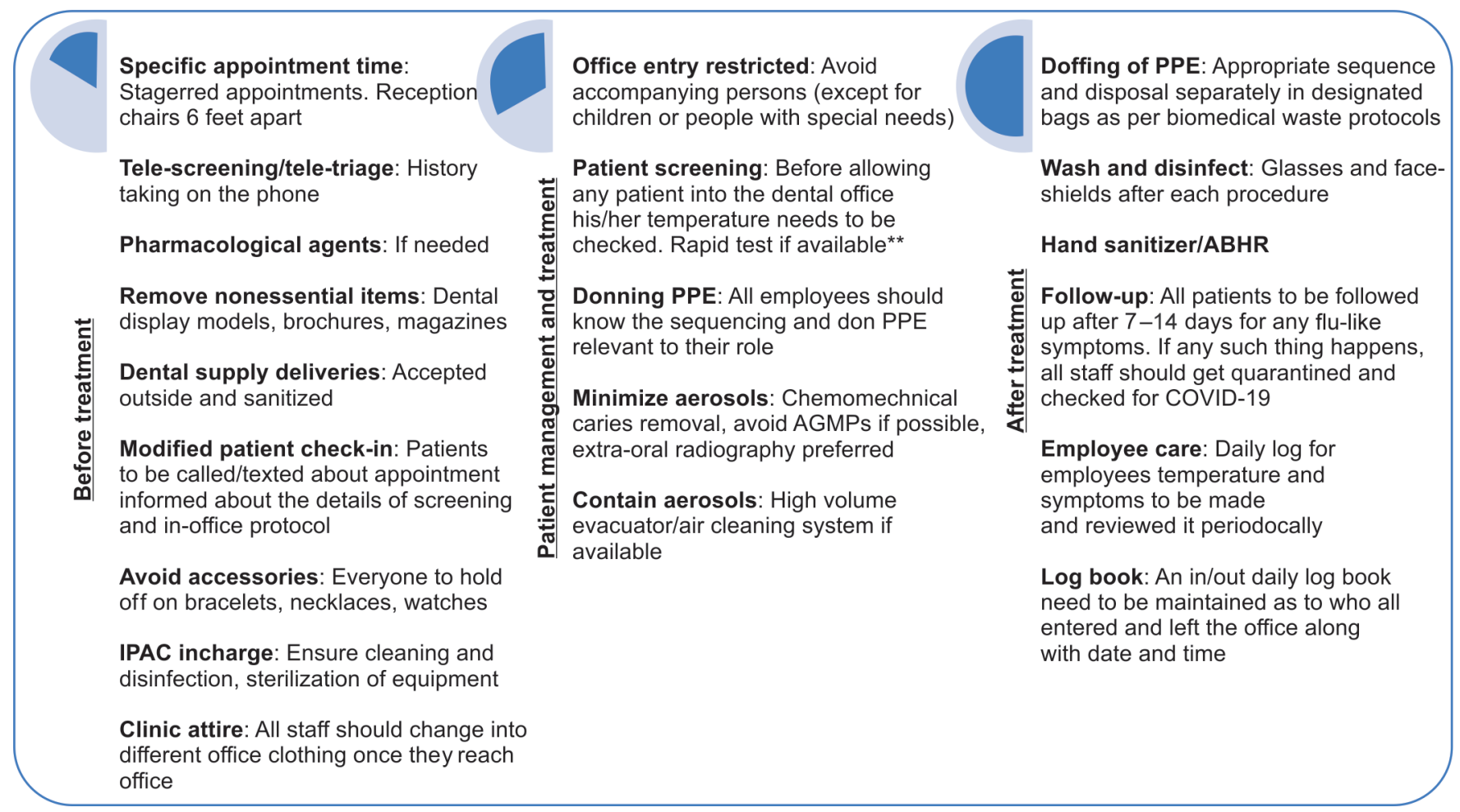

Fig. 2: Proposed clinic contingency plan

*This is a contingency plan outline, and can be used as a skeleton to formulate a customised plan for a dental practice while following the most updated national and international guidelines

**Sensitivity and accuracy of the test must be checked prior to use and interpretation 
Though teledentistry has now become an integral part of care, some patients may not be comfortable with it. Studies have reported that telehealth presented an impediment to traditional healthcare and many patients were discontented with the same, ${ }^{40,41}$ when their primary anticipations were not met. ${ }^{42}$ Also, while minor signs and symptoms may seem unimportant to the patient, these assumptions of aggressive telescreening are relying heavily on patients' information or lack thereof. Dentists should make the patient comfortable, gain their confidence, and encourage them to report even the mildest of symptoms, which they might usually ignore.

\section{Use of Pharmacological Agents}

Dental treatment of any suspected or confirmed COVID-19 patient ideally must be deferred for 2 weeks from the time of exposure. ${ }^{35}$ Analgesics and/or antibiotics can be considered as therapeutic agents in certain cases. During the peak of the pandemic dental treatments should be categorized according to the severity as well as, the extent of invasiveness and risk of the procedure, especially when the federal and local public health authorities have deferred elective treatment. Treatment should be considered after risk vs benefit evaluation ${ }^{43}$ keeping in mind the possibility of disease progression, as reversible pulpitis might progress to irreversible, irreversible to apical periodontitis, and further on. There might be consequent tooth loss as well. ${ }^{44}$ Dentistry might see a splurge of patients once life resumes its "normalcy" with patients presenting with dental problems of much more severity and poor prognosis.

\section{In-office Screening and Treatment}

If a patient requires in-person visit, temperature needs to be checked at the point of entry itself, preferably with a noncontact thermometer, ${ }^{3}$ followed by a questionnaire and rapid test if available. To avoid transmission, magazines, toys, and other unnecessary items must be removed from the clinic and appointments should be staggered. ${ }^{3}$ In pediatric dental setup, only one parent should accompany the child. Alcohol-based hand rub (ABHR) should be available at appropriate locations in the waiting area to help improve hand hygiene by children, parents, and staff. If treatment needs to be performed, informed consent ${ }^{2}$ must be obtained and the operatory must be prepared for the same.

\section{Preparation of the Operatory and Instruments}

Treatment of any suspected COVID-19 patient if required, must preferably utilize a negative pressure/airborne infection isolation room (AIIR). ${ }^{2}$ Furthermore, a portable high-efficiency particulate air (HEPA) filter with negative ion generator may be considered, ${ }^{45}$ which are available mostly in hospital based settings only. ${ }^{46}$

In a recent study, after SARS-CoV-2 application on copper and only cardboard, no live viable SARS-CoV-2 was observed after 4 and 24 hours, respectively. However, viable virus was more stable and discerned up to 72 hours on stainless steel and plastic. ${ }^{47}$ This recent ground-breaking research about the aerosol and surface viability of the virus might provide a beneficial implication for dentistry as well. Cardboard use as barriers and the use of coppercoated instruments instead of stainless steel may be considered as a substitute and further research is recommended for the same. ${ }^{47}$

\section{Hand Hygiene}

WHO recommended ABHR formulations with $80 \%$ ethanol or $75 \%$ 2-propanol, have been assessed against SARS-CoV and MERS-CoV, and were found to be effective. Benzalkonium chloride, however, has less efficiency than either of the alcohols, against coronaviruses. ${ }^{35,38}$
Due to the current situation, healthcare organizations that grapple with paucity of $A B H R$ can consider local production of formulations as described by the FDA Policy for Compounding of Certain AlcoholBased Hand Sanitizer Products. ${ }^{3}$

Few studies illustrate that poor compliance with hand hygiene practices remains a challenge for Infection Prevention and Control (IPAC) among practitioners all over the world who mistake gloving as a substitute for hand washing. ${ }^{48,49}$ Alcohol-based hand rub use should be encouraged between all patients, they should be provided in appropriate areas close to the health workers, and additionally hand-washing promoted when hands are visibly soiled.

\section{Personal Protective Equipment}

Use of custom-fit N95 respirator, eye protection, face shield, and overgown during AGMP on confirmed or suspected COVID-19

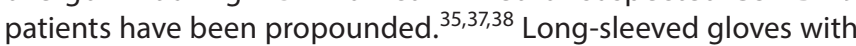
double-gloving technique, eyewear including side shields or fullface shields, and hair covers/hoods are recommended. ${ }^{35}$ The use of powered air-purifying respirator (PAPR) in invasive treatments is suggested by few. ${ }^{13,50}$

Donning a surgical mask or N95 is predicated on the size and dispersion of the respiratory secretions, and the dimension of droplets known to be contagious for a specific pathogen, rather than the size of the virus itself. ${ }^{51}$

Although wearing double gloves, overgown, and face/eye protection that have been overemphasized during AGMP along with PAPR in invasive treatments, ${ }^{13,50}$ but the reduced dexterity owing to the double layers of gloves, diminished visibility by flexible face shields, and back ache due to PAPRs may result in poor compliance. ${ }^{52}$ Thus, rather than donning everything, the most appropriate personal protective equipment (PPE) to be used in COVID-19 patients is contingent on the clinical procedure being performed. Association for the Advancement of Medical Instrumentation (AAMI)-level 2 gown, surgical mask with face shield, and single gloves are advisable for caretakers who are not involved in high-risk AGMP. ${ }^{53}$ For healthcare personnel present in the operatory during an AGMP, AAMI level-2 gown, N95 mask, eyeshield, head cover, and single gloves are advised; and practitioners performing AGMP, should deploy AAMI level-3 gown, neck cover, and two pairs of gloves. ${ }^{53}$

The coated fabric that has to be used must pass ISO 16603 and ISO 22612 testing for the usage of PPE kit. ${ }^{54}$ Another concern is contamination during doffing but abiding by doffing recommendations by CDC may lead to reduced crosscontamination, in comparison with a lack of guidance. ${ }^{55}$

Though this has not been paid heed to, nitrile gloves show better penetration resistance to viral load, when compared to latex. ${ }^{56}$ When comparing latex and nitrile gloves in terms of barrier performance, both were superior to vinyl gloves. ${ }^{57}$

\section{Minimizing Aerosols and Salivary Pathogens}

SARS-CoV-2 has been found to be susceptible to oxidation, hence, pre-procedural rinse incorporating oxidative agents like $1 \%$ hydrogen peroxide or $0.2 \%$ povidone iodine is advocated to reduce viral load, though substantial evidence is not available. ${ }^{38}$ Spraying local anesthetics must be avoided due to the propensity to disseminate the virus in aerosols. ${ }^{35,38}$ However, if treatment is to be performed under GA, lidocaine should be used before endotracheal intubation as coughing can produce aerosols. ${ }^{58}$ Furthermore, ultrasonic scalers, three-way syringes, and high-speed handpieces must be obviated. ${ }^{2}$ If indispensable, antiretraction 
handpieces ${ }^{35}$ or electric friction grip handpieces ${ }^{59}$ must be used to prevent aspiration and expulsion of debris and fluids. ${ }^{35}$ Suction, low or high volume can reduce aerosol production. ${ }^{41,42}$ If restorative or endodontic treatment is necessary, chemomechanical caries removal, such as Carisolv and papain gel, is a viable alternative. ${ }^{35,60}$ Also, silver diamine fluoride and GIC can be used to restore teeth to prevent disease progression ${ }^{61,62}$ (Table 1).
The reduction in bacteria-laden aerosols with rubber dam has been recommended for aerosol-generating procedures by Peng et al. ${ }^{35}$ Studies by Samaranayake et al. have suggested $78 \%$ reduction by and $70-88 \%$ reported by Cochran et al. ${ }^{63}$ Hence, caution needs to be observed despite its use. Extraoral radiography must be preferred over intraoral to reduce saliva production. ${ }^{2,35,38}$ In case intraoral digital films are needed, supplemental barrier protection with finger

Table 1: Proposed pediatric patient management

\begin{tabular}{|c|c|c|c|}
\hline \multirow[b]{2}{*}{ Dental problems } & \multirow[b]{2}{*}{ Home care } & \multicolumn{2}{|r|}{ Clinical care } \\
\hline & & Avoid & Advised \\
\hline Preventive procedures & $\begin{array}{l}\text { Oral hygiene instructions }(\mathrm{OHI}) \text { : } \\
\text { - Brushing with fluoridated toothpaste* } \\
\text { - Flossing } \\
\text { Diet modification: } \\
\text { - Advise fruits and vegetables } \\
\text { - Roughage and fiber } \\
\text { - Avoid sharing of utensils, fermentable } \\
\text { carbohydrates, soft drinks, energy } \\
\text { drinks }\end{array}$ & - Three-way syringe & $\begin{array}{ll}\text { - } & \text { Diet counseling } \\
\text { - } & \text { Topical fluoride gel } \\
\text { - } & \text { Topical fluoride varnish } \\
\text { - } & \text { Pit and fissure sealants }\end{array}$ \\
\hline \multicolumn{4}{|l|}{ Interceptive procedures } \\
\hline $\begin{array}{l}\text { Space maintainers/ } \\
\text { palatal expanders }\end{array}$ & Proper storage and cleaning & $\begin{array}{l}\text { Removable space } \\
\text { maintainer (saliva spread) }\end{array}$ & Fixed space maintainer \\
\hline $\begin{array}{l}\text { (1) Broken: If partially } \\
\text { glued and still } \\
\text { present in mouth }\end{array}$ & $\begin{array}{l}\text { (1) It can be placed back in position but } \\
\text { further screw-activation to be avoided, } \\
\text { dentist/pedodontist to be informed }\end{array}$ & & \\
\hline (2) Dislodged & $\begin{array}{l}\text { (2) It should be kept safe and dentist/ } \\
\text { pedodontist should be informed }\end{array}$ & & \\
\hline $\begin{array}{l}\text { Interception of oral } \\
\text { habits/orthodontic } \\
\text { appliances }\end{array}$ & $\begin{array}{l}\text { - } \text { Counselling } \\
\text { - } \text { Oral exercise }\end{array}$ & & $\begin{array}{l}\text { - Counselling } \\
\text { - Oral exercise training } \\
\text { - } \text { Fixed appliances preferred }\end{array}$ \\
\hline $\begin{array}{l}\text { Fixed orthodontics } \\
\text { (1) Broken bracket } \\
\text { (2) Piercing wire }\end{array}$ & $\begin{array}{l}\text { (1) Relief- wax, for mouth sores, patient } \\
\text { can be advised topical anesthetic/ } \\
\text { analgesic gels }\end{array}$ & & $\begin{array}{l}\text { (1) Adhesive pre-coated bracket } \\
\text { can be used to reduce aerosol } \\
\text { production }\end{array}$ \\
\hline & $\begin{array}{l}\text { (2) A cotton swab or clean pencil eraser can } \\
\text { be used to push the wire so it flattens } \\
\text { against the tooth }\end{array}$ & & $\begin{array}{l}\text { (2) Cut the excess wire and } \\
\text { dispose it as medical waste } \\
\text { carefully }\end{array}$ \\
\hline \multicolumn{4}{|c|}{ Restorative and endodontic procedures } \\
\hline $\begin{array}{l}\text { Caries/reversible and } \\
\text { irreversible pulpitis }\end{array}$ & $\begin{array}{l}\text { - Rinse and keep cavity clean. } \\
\text { - Over the counter (OTC) analgesics, } \\
\text { antibiotics if required. } \\
\text { - OHI }\end{array}$ & $\begin{array}{l}\text { - Aerosol-producing } \\
\text { procedures }\end{array}$ & $\begin{array}{l}\text { - Chemomechanical caries } \\
\text { - Use of sharp spoon excavator } \\
\text { - } \text { Art } \\
\text { - Smart: SDF modified art/caries } \\
\text { arrest } \\
\text { - Extraction is preferred for } \\
\text { deciduous teeth. } \\
\text { - Partial pulpotomy, pulpectomy } \\
\text { under rubber-dam in } \\
\text { - Permanent teeth (to be } \\
\text { followed with root canal } \\
\text { Treatment later) } \\
\text { - Use of micromotor for access } \\
\text { opening } \\
\text { - Single sitting preferred } \\
\text { If crowns needed, stainless } \\
\text { steel/hall technique }\end{array}$ \\
\hline
\end{tabular}


Contd...

\begin{tabular}{|c|c|c|c|}
\hline \multirow[b]{2}{*}{ Dental problems } & \multirow[b]{2}{*}{ Home care } & \multicolumn{2}{|r|}{ Clinical care } \\
\hline & & Avoid & Advised \\
\hline \multicolumn{4}{|l|}{ Gingival procedures } \\
\hline Gingivitis & $\begin{array}{l}\text { - } \mathrm{OHI} \\
\text { - } \text { Oral water irrigators }\end{array}$ & - Ultrasonic scalers & $\begin{array}{l}\text { - Hand scaling with intermittent } \\
\text { antimicrobial rinsing }\end{array}$ \\
\hline $\begin{array}{l}\text { Pericoronitis or eruption } \\
\text { gingivitis }\end{array}$ & $\begin{array}{ll}\cdot & \text { OHI } \\
\cdot & \text { OTC analgesics } \\
\text { - } & \text { Warm saline rinses } \\
\text { - } & \text { Oral water irrigators }\end{array}$ & $\begin{array}{l}\text { - LA spray } \\
\text { - Irrigation }\end{array}$ & $\begin{array}{l}\text { - } \text { Preoperative mouth rinse } \\
\text { - LA gel } \\
\text { - Operculectomy }\end{array}$ \\
\hline \multicolumn{4}{|l|}{ Oral surgical procedures } \\
\hline \multirow[t]{2}{*}{ Extraction/exodontia } & & $\begin{array}{l}\text { - LA spray } \\
\text { - } \text { Non-resorbable } \\
\text { sutures }\end{array}$ & $\begin{array}{l}\text { - Preoperative mouth rinse } \\
\text { - LA gel }\end{array}$ \\
\hline & & & - Resorbable sutures \\
\hline Trauma** & & & $\begin{array}{l}\text { (1) Smoothening of the tooth with } \\
\text { disks on contra-angle handpiece } \\
\text { followed by GIC }\end{array}$ \\
\hline (1) Enamel fracture & & & (2) Splinting \\
\hline (2) Luxation & & & $\begin{array}{l}\text { (3) Reimplantation for permanenent } \\
\text { tooth (if conditions satisfied) }\end{array}$ \\
\hline (3) Avulsion & & & (4) Extraction \\
\hline \multicolumn{4}{|l|}{$\begin{array}{l}\text { (4) Deciduous tooth } \\
\text { trauma posing } \\
\text { risk to permanent } \\
\text { successor/mobile }\end{array}$} \\
\hline Radiographs & & $\begin{array}{l}\text { - } \text { CCD/CMOS } \\
\text { (Radiovisography) }\end{array}$ & $\begin{array}{l}\text { - Extra-oral } \\
\text { - If intra-oral with double barrier } \\
\text { and finger cots }\end{array}$ \\
\hline
\end{tabular}

${ }^{*}$ Above the age of 5 years

**Thorough evaluation and clinical signs and symptoms to be noted, risk vs benefit evaluation and individualistic approach required.

This table has been created using information from Suri et al., ${ }^{3}$ Alharbi et al.., ${ }^{43}$ Peng et al., ${ }^{35}$ and Meng et al. ${ }^{37}$

cots is highly recommended to prevent patient cross-contamination, as plastic barrier sheaths alone have frequent leakage. ${ }^{64}$

Aerosols are the foremost reason for panic, owing to cross infection through it. During this pandemic, high-volume evacuators (HVEs) may offer a promising solution by controlling aerosol particles before they leave the mouth and can reduce $90-98 \%$ of aerosols, regardless of source. ${ }^{35,37,65}$ Air-cleaning systems also used for the same purpose significantly reduce the potentially hazardous aerosols created as shown by early studies; but still there is a dearth of published evidence for the same. ${ }^{66}$

\section{Postprocedure Disinfection and Decontamination}

Following every dental procedure, rigorous disinfection of all the surrounding surfaces should be carried out. Therefore, there should be a time lapse of at least an hour between subsequent appointments to perform thorough decontamination. This has also been advocated by Ti and colleagues. ${ }^{52}$ Moreover, there may be a backflow of pathogens with the use of handpieces in the water tubes of the dental chair. Owing to this, purging should be appropriately done. All sterilizable instruments must be timely cleaned, disinfected, and sterilized. All disposables should be considered highly infected medical waste and discarded appropriately. ${ }^{27,58}$ The potency of human coronaviruses on inanimate objects is up to 9 days at room temperature. Although data on the transmissibility of SARS-CoV-2 from contaminated surfaces to hands were not found, 5-second contact time has been documented to transmit $31.6 \%$ of influenza A virus to hands. ${ }^{67,68}$ Ethanol at concentrations between $62 \%$ and $71 \%, 0.1-0.5 \%$ sodium hypochlorite, and $2 \%$ glutaraldehyde reduced coronavirus infectivity within 1 minute exposure time. A comparable effect is expected against the SARSCoV-2 and these agents should be used for appropriate surface disinfection. ${ }^{67}$ Hydrogen peroxide vaporizer can also be used to decontaminate the operatory. ${ }^{3,52}$

Various advisories and specifications have been put forward by the governing authorities. Despite these recommendations, absolute infection control measures sometimes require constant reiteration. ${ }^{49}$ Therefore, the administration of the dental healthcare practice must make sure and evolve infection prevention and occupational health programs. Written infection prevention policies and procedures including standard operating protocols for the services provided by the facility should be formulated and maintained. Provision of supplies necessary for hand hygiene products in easily accessible areas should be ensured. Definitive infection prevention education and training must be made available. The complete team must be provided with appropriate PPE for the procedure to be performed and their role in the same, to prevent droplet and contact infections. Dental healthcare settings must institute procedural protocols for donning and doffing PPE. Prior to the treatment, the dental team must identify and review 
the in-procedural protocols, and plan ahead for triage, pre-procedure operatory preparation, minimizing aerosols during procedure and postprocedure disinfection. Routine evaluation and reevaluation of the infection prevention program, including adherence to infection prevention practices should be established.

\section{Conclusion}

- In these unforeseen times, events are unfolding rapidly. Hence, all dental practitioners should be abreast with the latest news and guidelines in accordance with state, federal, national, and international bodies.

- Especially in pediatric dentistry, children should be made to feel comfortable with the new PPE and protocols in the dental practice setting in order to reduce fear and increase cooperation.

- A customized approach should be taken by practices to safeguard patients, patients' families, and dental healthcare personnel during and after this pandemic.

- Although currently catastrophic, even after the critical peak of the outbreak has been contained, stringent IPAC protocols need to be updated, followed, and reviewed.

\section{References}

1. Samaranayake LP, Peiris M. Severe acute respiratory syndrome and dentistry: a retrospective view. J Am Dent Assoc 2004;135(9):12921302. DOI: 10.14219/jada.archive.2004.0405.

2. Ather A, Patel B, Ruparel NB, et al. Coronavirus disease 19 (COVID-19): implications for clinical dental care. J Endod 2020;46(5):584-595. DOI: 10.1016/j.joen.2020.03.008[Accessed on 2020].

3. Suri S, Vandersluis YR, Kochhar AS, et al. Clinical orthodontic management during the COVID-19 pandemic. Angle Orthod 2020(4). DOI: 10.2319/033120-236.1[Accessed on May 1, 2020].

4. Wilder-Smith A, Chiew CJ, Lee VJ. Can we contain the COVID-19 outbreak with the same measures as for SARS? Lancet Infect Dis 2020(5). DOI: 10.1016/S1473-3099(20)30129-8[Accessed on May 1, 2020].

5. Riou J, Althaus CL. Pattern of early human-to-human transmission of Wuhan 2019 novel coronavirus (2019-nCoV), December 2019 to January 2020. Euro Surveill 2020;25(4):2000058. DOI: 10.2807/15607917.ES.2020.25.4.2000058.

6. Zhao S, Ling K, Yan $\mathrm{H}$, et al. Anesthetic management of patients with COVID 19 infections during emergency procedures. J Cardiothorac Vasc Anesth 2020;34(5):1125-1131. DOI: 10.1053/j.jvca.2020.02.039.

7. Yu P, Zhu J, Zhang Z, et al. A familial cluster of infection associated with the 2019 novel coronavirus indicating potential person-to-person transmission during the incubation period. J Infect Dis 2020. jiaa077. [Accessed on May 1, 2020].

8. Huang R, Xia J, Chen Y, et al. A family cluster of SARS-CoV-2 infection involving 11 patients in Nanjing, China. Lancet Infect Dis 2020;20(5):534-535. DOI: 10.1016/S1473-3099(20)30147-X[Accessed on May 1, 2020].

9. Pan $X$, Chen $D, X i a Y$, et al. Asymptomatic cases in a family cluster with SARS-CoV-2 infection. Lancet Infect Dis 2020;20(4):410-411. DOI: 10.1016/S1473-3099(20)30114-6.

10. Wei WE, Li Z, Chiew CJ, et al. Presymptomatic transmission of SARSCoV-2 - Singapore, january 23-march 16. 2020. MMWR Morb Mortal Wkly Rep 2020;69(14):411-415. DOI: 10.15585/mmwr.mm6914e1.

11. Coronavirus disease, 2019 (COVID-19) Situation Report - 73 https://www.who.int/docs/default-source/coronaviruse/situationreports/20200402-sitrep-73-covid-19.pdf?sfvrsn=5ae25bc7_2. [Accessed on May 1,2020].

12. Coronavirus disease (COVID-19): Summary of assumptions Updated: April 13, 2020 https://www.canada.ca/en/public-health/services/ diseases/2019-novel-coronavirus-infection/health-professionals/ assumptions.html\#a1. [Accessed on May 1, 2020].
13. Coulthard P. Dentistry and coronavirus (COVID-19) - moral decisionmaking. Br Dent J 2020;7(228):503-505. DOI: 10.1038/s41415-0201482-1.

14. Belser JA, Rota PA, Tumpey TM. Ocular tropism of respiratory viruses. Microbiol Mol Biol Rev 2013;7(1):144-156. DOI: 10.1128/MMBR. 00058-12.

15. Lu J, Gu J, Li K, et al. COVID-19 outbreak associated with air conditioning in restaurant, Guangzhou, China, 2020. Emerg Infect Dis 2020;26(7):1628-1631. DOI: 10.3201/eid2607.200764.

16. Spinato $\mathrm{G}$, Fabbris $\mathrm{C}$, Polesel J, et al. Alterations in smell or taste in mildly symptomatic outpatients with SARS-CoV-2 infection. JAMA 2020;323(20):2089-2090. DOI: 10.1001/jama.2020.6771[Accessed on May 1, 2020].

17. Fang L, Karakiulakis G, Roth M. Are patients with hypertension and diabetes mellitus at increased risk for COVID-19 infection? Lancet Respir Med 2020;8(4):e21. DOI: 10.1016/S2213-2600(20)30116-8.

18. Yang J, Zheng Y, Gou X, et al. Prevalence of comorbidities and its effects in coronavirus disease 2019 patients: a systematic review and meta-analysis. Int J Infect Dis 2020;94:91-95. DOI: 10.1016/ j.ijid.2020.03.017[Accessed on May 1, 2020].

19. Al-Muharraqi MA. Testing recommendation for COVID-19 (SARSCoV-2) in patients planned for surgery - continuing the service and 'suppressing' the pandemic. Br J Oral Maxillofac Surg 2020;S02664356(20):30164-30169. [Accessed on May 1,2020].

20. Wang P, Anderson N, Pan Y, et al. The SARS-CoV-2 outbreak: diagnosis, infection prevention, and public perception. Clin Chem 2020;7(5):11. DOI: 10.1093/clinchem/hvaa080.

21. Abbasi J. The promise and peril of antibody testing for COVID-19. JAMA 2020(19). DOI: 10.1001/jama.2020.6170[Accessed on May 1,2020].

22. Patel R, Babady E, Theel ES, et al. Report from the american society for microbiology COVID-19 international summit, 23 march 2020:Value of diagnostic testing for SARS-CoV-2/COVID-19. mBio 2020;11(2):e0072220. DOI: $10.1128 / \mathrm{mBio} .00722-20$.

23. Industry Hotline: Coronavirus COVID-19 Diagnostic Tests and Shortages in Emergency Use Authorizations https://www.fda. gov/medical-devices/emergency-situations-medical-devices/ emergency-use-authorizations\#covid19ivd. [Accessed on May 1,2020].

24. Klompas M. Coronavirus disease 2019 (COVID-19): protecting hospitals from the invisible. Ann Intern Med 2020;172(9):619-620. DOI: 10.7326/ M20-0751[Accessed on May 1, 2020].

25. Hoffman T, Nissen K, Krambrich J, et al. Evaluation of a COVID-19 IgM and IgG rapid test; an efficient tool for assessment of past exposure to SARS-CoV-2. Infect Ecol Epidemiol 2020;10(1):1754538. DOI: 10.1080/20008686.2020.1754538.

26. False Negatives in Quick COVID-19 Test Near 15 Percent:Study https:// www.the-scientist.com/news-opinion/false-negatives-in-quickcovid-19-test-near-15-percent-study-67451. [Accessed on May 1, 2020].

27. Bali RK, Chaudhry K. Maxillofacial surgery and COVID-19, the pandemic!!. J Maxillofac Oral Surg 2020;19(2):159-161. DOI: 10.1007/ s12663-020-01361-8.

28. To KK-W, Tsang OT-Y, Yip CCY, et al. Consistent detection of 2019 novel coronavirus in saliva. Clin Infect Dis 2020. ciaa149. DOI: 10.1093/cid/ ciaa149[Accessed on 27 April 2020].

29. Wyllie AL, Fournier J, Massana AC, et al., Saliva is more sensitive for SARS-CoV-2 detection in COVID-19 patients than nasopharyngeal swabs. medRxiv 2020.04.16.20067835. [Accessed on 27 April 2020].

30. Ottestad W, Søvik S. COVID-19 patients with respiratory failure: what can we learn from aviation medicine? Br J Anaesth 2020. DOI: 10.1016/j.bja.2020.04.012[Accessed on May 1, 2020].

31. Rathi $S$, Ish $P$, Kalantri $A$, et al. Hydroxychloroquine prophylaxis for COVID-19 contacts in India. Lancet Infect Dis 2020. DOI: 10.1016/ S1473-3099(20)30313-3[Accessed on May 1, 2020].

32. Chen CY, Wang FL, Lin CC. Chronic hydroxychloroquine use associated with QT prolongation and refractory ventricular 
arrhythmia. Clin Toxicol (Phila) 2006;44(2):173-175. DOI: 10.1080/ 15563650500514558.

33. Fihn SD, Perencevich E, Bradley SM. Caution needed on the use of chloroquine and hydroxychloroquine for coronavirus disease 2019. JAMA Netw Open 2020;3(4.23):e209035. DOI: 10.1001/ jamanetworkopen.2020.9035.

34. Principi N, Esposito S. Chloroquine or hydroxychloroquine for prophylaxis of COVID-19. Lancet Infect Dis 2020. DOI: 10.1016/S14733099(20)30296-6[Accessed on May 1, 2020].

35. Peng X, Xu X, Li Y, et al. Transmission routes of 2019-nCoV and controls in dental practice. Int J Oral Sci 2020;12(1):9. DOI: 10.1038/s41368-0200075-9.

36. Guo H, Zhou Y, Liu X, et al. The impact of the COVID-19 epidemic on the utilization of emergency dental services. J Dent Sci [Internet] 2020. DOI: 10.1016/j.jds.2020.02.002[Accessed on May 1, 2020].

37. Meng L, Hua F, Bian Z. Coronavirus disease 2019 (COVID-19): emerging and future challenges for dental and oral medicine. J Dent Res 2020;99(5):481-487. DOI: 10.1177/0022034520914246.

38. Izzetti R, Nisi M, Gabriele M, et al. COVID-19 transmission in dental practice: brief review of preventive measures in Italy. J Dent Res 2020. DOI: 10.1177/002203452092058022034520920580 [Accessed on May 1, 2020].

39. Coronavirus Disease 2019 (COVID-19). Centers for Disease Control and Prevention. [Internet] Available from: https://www.cdc.gov/ coronavirus/2019-ncov/symptoms-testing/testing.html. [Accessed on May 1, 2020].

40. Cochrane Effective Practice and Organisation of Care. Effective practice and organisation of care (EPOC) Resources for review authors https://epoc.cochrane.org/resources/epoc-resources-reviewauthors. [Accessed on May 1, 2020].

41. Lake R, Georgiou A, Li J, et al. The quality, safety and governance of telephone triage and advice services - an overview of evidence from systematic reviews. BMC Health Serv Res 2017;17(1):614. DOI: 10.1186/ s12913-017-2564-x.

42. Leibowitz R, Day S, Dunt D. A systematic review of the effect of different models of after-hours primary medical care services on clinical outcome, medical workload, and patient and GP satisfaction. Fam Pract 2003;20(3):311-317. DOI: 10.1093/fampra/cmg313.

43. Alharbi A, Alharbi S, Alqaidi S. Guidelines for dental care Provision during the COVID-19 pandemic. Saudi Dent J 2020;32(4):181-186. DOI: 10.1016/j.sdentj.2020.04.001[Accessed on May 1, 2020].

44. Yu J, Zhang T, ZhaoD, et al. Characteristics of endodontic emergencies during Covid-19 Outbreak IN Wuhan. J Endod 2020;46(6):730-735. DOI: 10.1016/j.joen.2020.04.001[Accessed on May 1, 2020].

45. Elias B, Bar-Yam Y. Could air filtration reduce COVID-19 severity and spread?. New England Complex Systems Institute; 2020.

46. Miller SL, Clements N, Elliott SA, et al. Implementing a negativepressure isolation ward for a surge in airborne infectious patients. Am J Infect Control 2017;45(6):652-659. DOI: 10.1016/j.ajic.2017.01.029.

47. van Doremalen N, Bushmaker T, Morris DH, et al. Aerosol and surface stability of SARS-CoV-2 as compared with SARS-CoV-1. N Engl J Med 2020;382(16):1564-1567. DOI: 10.1056/NEJMc2004973.

48. Pittet D. Hand hygiene: from research to action. J Infect Prev 2017;18(3):100-102. DOI: 10.1177/1757177417705191.

49. Ibrahim NK, Alwafi HA, Sangoof SO, et al. Cross-infection and infection control in dentistry: knowledge, attitude and practice of patients attended dental clinics in king Abdulaziz university hospital, Jeddah, Saudi Arabia. J Infect Public Health 2017;10(4):438-445. DOI: 10.1016/ j.jiph.2016.06.002.

50. Wax RS, Christian MD. Practical recommendations for critical care and anesthesiology teams caring for novel coronavirus (2019-nCoV) patients. Can J Anaesth 2020;67(5):568-576. DOI: 10.1007/s12630-02001591-x.
51. Lockhart SL, Duggan LV, Wax RS, et al. Personal protective equipment (PPE) for both anesthesiologists and other airway managers: principles and practice during the COVID-19 pandemic. Can J Anesth/J Can Anesth 2020;67(8):1005-1015. DOI: 10.1007/s12630-020-01673w[Accessed on May 1, 2020].

52. Ti LK, Ang LS, Foong TW, et al. What we do when a COVID-19 patient needs an operation: operating room preparation and guidance. Can J Anesth [Internet] 2020;67(6):756-758. DOI: 10.1007/s12630-020-016174[Accessed on May 1, 2020].

53. Lockhart SL, Naidu JJ, Badh CS, et al. Simulation as a tool for assessing and evolving your current personal protective equipment: lessons learned during the coronavirus disease (COVID-19) pandemic. Can J Anaesth 2020;67(7):895-896. DOI: 10.1007/s12630-020-01638z[Accessed on May 1, 2020].

54. Clothing for protection against infectious agents - Test method for resistance to dry microbial penetration https://www.iso.org/ standard/35058.html. [Accessed on May 1,2020].

55. Verbeek JH, Rajamaki B, ljaz S, et al. Personal Protective equipment for preventing highly infectious diseases due to exposure to contaminated body fluids in healthcare staff. Cochrane Database Syst Rev 2020;15(4):CD011621.

56. O'Connell K, El-Masri M, Broyles J, et al. Testing for viral penetration of non-latex surgical and examination gloves: a comparison of three methods. Clin Microbiol Infect 2004;10(4):322-326. DOI: 10.1111/j.1198-743X.2004.00848.x.

57. Rego A, Roley L. In-use barrier integrity of gloves: latex and nitrile superior to vinyl. Am J Infect Control 1999;27(5):405-410. DOI: 10.1016/ s0196-6553(99)70006-4.

58. Kim HJ, Ko JS, Kim T-Y. Recommendations for anesthesia in patients suspected of coronavirus 2019-nCoV infection. Korean J Anesthesiol 2020;73(2):89-91. DOI: 10.4097/kja.20110.

59. Bhandary N, Desai A, Shetty YB. High speed handpieces. J Int Oral Health 2014;6(1):130-132.

60. Kochhar GK, Srivastava N, Pandit I, et al. An evaluation of different caries removal techniques in primary teeth: a comparitive clinical study. Int J Clin Pediatr Dent 2011;36(1):5-10. DOI: 10.17796/jcpd.36. 1.u242114j68847215.

61. Rajendra A, Veitz-Keenan A, Oliveira BH, et al. Topical silver diamine fluoride for managing dental caries in children and adults. Cochrane Database Syst Rev 2017;7:CD012718. DOI: 10.1002/14651858. CD012718.

62. Wang Y, Zhou CC, Shu R, et al. Oral health management of children during the epidemic period of coronavirus disease 2019. Sichuan Da Xue Xue Bao Yi Xue Ban 2020;51(2):151-154. DOI: 10.12182/20200360101[Article in Chinese].

63. Cochran MA, Miller $\mathrm{CH}$, Sheldrake MA. The efficacy of the rubber dam as a barrier to the spread of microorganisms during dental treatment. J Am Dent Assoc 1989;119(1):141-144. DOI: 10.14219/jada. archive.1989.0131.

64. Hokett SD, Honey JR, Ruiz F, et al. Assessing the effectiveness of direct digital radiography barrier sheaths and finger cots. J Am Dent Assoc 2000;131(4):463-467. DOI: 10.14219/jada.archive.2000.0202.

65. Harrel SK. Contaminated dental aerosols. Dimens Dent Hyg 2003;1(6):16-20.

66. Hallier C, Williams DW, Potts AJ, et al. A pilot study of bioaerosol reduction using an air cleaning system during dental procedures. Br Dent J 2010;209(8):E14. DOI: 10.1038/sj.bdj.2010.975.

67. Kampf G, Todt D, Pfaender S, et al. Persistence of coronaviruses on inanimate surfaces and their inactivation with biocidal agents. J Hosp Infect 2020;104(3):246-251. DOI: 10.1016/j.jhin.2020.01.022.

68. Bean B, Moore BM, Sterner B, et al. Survival of influenza viruses on environmental surfaces. J Infect Dis 1982;146(1):47-51. DOI: 10.1093/ infdis/146.1.47. 